\title{
Title: The symbolic meaning of artifacts for the workplace identity of women in academia.
}

\begin{abstract}
Purpose

The aim of this research is to investigate the symbolic meaning attributed by women in academia to workplace artifacts.
\end{abstract}

\section{Design/methodology/approach}

The research approach is that of auto-ethnography, whereby the authors, as researchers and participants, explore symbolic meaning from artifacts in their working environment.

\section{Findings}

Three themes emerged on the symbolic meaning from artifacts for women in academia. The theme of 'affect' revealed women as uncomfortable in their surroundings; 'representation', renders women invisible within the institution; women felt themselves to be under 'surveillance'.

\section{Research limitations/implications}

The investigation is limited to one university, which limits generalisability. The implication is to replicate this auto-ethnographical study in other institutions of higher education.

\section{Practical implications}

Implies that architectural, institutional and personal artifacts play an important role in defining women's workplace identity.

\section{Social implications}

Women in academia identify themselves as 'outsiders' in the workplace because of the symbolic meaning they attribute to artifacts.

\section{Originality/value}

This study on women in academia is original as it is the first auto-ethnographical study on artifacts in an international institution of higher education.

Keywords: Auto-ethnography; artifacts; symbolism; aesthetics; identity; emotional meaning. 


\section{Introduction}

It is important to investigate the way women in academia identify with the workplace because man has historically been identified as the ideal and the preferred worker (Allan, 2011; Ramarajan et al., in press). There are two further reasons for such an investigation: one, a seeming lack of progress for women in university careers (AACSB, 2013; FT.com, 2012; Stout et al., 2007), and two, the relative absence of women in academia depicted in organisational studies (Fotaki, 2012; Haynes and Fearfull, 2008).

Workplace identity has been recognised as a social construction, and we, as women in academia, aimed to discover how our identity is mediated within that physical setting (Alvesson and Willmott, 2002; Ely, 1995; Strati, 1998). We therefore employed an autoethnographical approach to collect data about the symbolic meaning of artifacts in the workplace. Catalysed by a study on physical identity markers, developed by Elsbach (2006), we found seven artifacts of particular significance to women in the workplace. Symbolic meanings attributed to the artifacts by the research participants/authors were classified into three themes, 'affect', 'representation' and 'surveillance'. These themes revealed women in academia experienced negative emotions from workplace artifacts - the environment as uncomfortable, a place where they were rendered invisible or under surveillance (Warren, 2002). A discussion about the symbolic meaning of artifacts reinforces that women in academia are identified as outsiders in the workplace (Fotaki, 2012).

The investigation is limited to one international university, and its value lies in the original context of an international institution of higher education. The study contributes to the body of knowledge about symbolic meaning for women's workplace identity (Dutton et al., 1994). A contribution to theory is the impact of architectural, institutional and personal artifacts on women's inclusion and opportunity in academia. Furthermore, the practical contribution is management of workplace artifacts contributes to women's workplace identity. 


\section{Literature review}

\section{Context}

Women represent a professional minority in research universities, and that position has not changed over time (Exum et al., 1984; Fotaki, 2012; O'Connor et al., 1999). As well, research reveals how the small proportion of women in powerful positions affects their workplace identity (Ely, 1995; Newell and Bradshaw, 1998). This study, therefore, places a spotlight on the status of women in academia, drawing on the authors' experience particularly as faculty and administrators in the context of business schools. The setting for this study is that of an international university, identified as such for three reasons: 1) the university is located outside Europe and the USA; 2) the university employs multi-national faculty; 3) the university's student body represents over 80 nationalities.

\section{The status of women in higher education}

Haynes and Fearfull (2008) point to the low percentage of women in academic positions in business and management disciplines (34\%), and this statistic is underscored by recent data as supplied in the 'Financial Times' ranking of business schools (FT.com, 2013). The faculty composition at each of the 'top' 10 business schools is more than $75 \%$ men; seven of the 10 report governance boards with less than $25 \%$ female membership; yet $9 / 10$ of those same institutions report a higher percentage of female students when compared to women in the faculty (FT.com, 2013). The European business schools indicate a similar trend, as 9/10 of those top schools have more than two-thirds male faculty (FT.com, 2013). Furthermore, men generally hold senior positions in academic administration; i.e. less than $10 \%$ of business schools globally have female Deans (AACSB, 2013).

These reported figures are also reflected in the reality of other international business schools, including the anonymous school in this study (Fujita, 2006). Upon examination, we found that in the academic ranking of the business school faculty, the more senior the status, the 
lower the percentage of women holding that status. This situation occurs despite the prevalence of female students who now outnumber male students in many disciplines internationally, and this is so in the country of study (Kirk and Napier, 2009). A proposal has been made to turn attention to these issues through the inclusion of gender balance in the scoring of business school rankings (Grove, 2013).

Hopfl and Matilal (2007) suggest that the 'lady vanishes' in senior levels of organisational hierarchies, and Morley (2014) that women as leaders are 'lost' to the global academy. The data given in the previous paragraph reveals, for the context of American and European business school faculty and administration, a replication of the vanishing and lost syndromes. The concept of a "leaky pipeline" (Blickenstaff, 2005, p. 369) also provides a strong metaphor for the attrition of women in the higher echelons of business school academia, "whereby large numbers enter the system, but some of these are leaked at various points, so that only a proportion reaches the end of the pipe" (Todd et al., p. 766). Furthermore, the situation has not changed overtime, as Fotaki (2013) emphasises that there has not been an increase in women in senior positions in business schools over the last decade.

A female MIT Professor poignantly describes how women may experience "death by a thousand pin pricks" (Todd et al., 2008, p 767). An example of such 'a pin prick' is the continuing image of the worker as male in photographs (Bleijenbergh et al., 2012), which repeatedly signals and re-emphasises the lower representation and rank of women in business schools, "especially among the senior faculty" (Verhaegen, 2005, p. 813). Men are more public and visible in a business school, and photographic images serve to reiterate their numbers and senior status (Chanana, 2003). Warren (2002) conducted a workplace ethnography noting that the visible in photographs is over emphasised rather than adding value in "their capacity to help visualize the invisible" (p. 233). Thus, when men are seen in workplace photographs, they become visible, but the non-representation of women is 
overlooked, i.e. is 'un-visualised'. At the same time, the lack of women's images in the workplace emphasises that "women tend to adopt a more feminine position by being more private, invisible" (Haynes and Fearfull, 2008, p. 193). Traditional debates about influence in the workplace, and different spheres of work based on gender, continue as men are 'on show' (public space) and women are invisible (private space).

Paradoxically, the concept of 'surplus visibility' provides a further example of the pin pricks, whereby women at senior levels come under increased observation because they are so exceptional and noticeable (Allan, 2011). This point is studied in the context of tokenism (Jackson et al., 1995),

women and minorities are also highly visible to members of the majority group. As a consequence of this increased visibility, they are subjected to increased stress that derives from higher performance pressure (Tapia et al. 2004, p. 88).

Thus, yet another barrier to visibility is erected for aspiring women faculty and administrators as they become wary of opening themselves to such close scrutiny.

As workplaces are traditionally an inhospitable fit for women, it cannot therefore be inherently a women's problem (Tapia and Kvasny, 2004). Any 'problem' as such involves intrinsic biases held, and affects all people within the organisation (Ramarajan et al., 2012). Consequently, in this article there is a move towards consideration of the position of women in academia as an institutional issue. When the recruitment, retention, progress and status of women in academia is wanting, it prevails on researchers to study why this is so. Further insight is therefore needed about women's workplace identity within the environment of academia.

\section{The value and loss of workplace identity}

The notion of workplace identity is derived from the concept of "social identity", because employees as individuals are members of many different "social groups" (Dutton et al., 1994, p. 242). Social identity is self-identification through connection with a particular group 
(Elsbach, 2006), one such social group is that of gender (woman), another is membership within a particular institution or profession (university, academia) (Alvesson and Willmott, 2002; Dutton et al., 1994). The definition for workplace identity that suits our purpose is "an individual's central and enduring status and distinctiveness .....in the workplace" (Elsbach, 2004, p. 100). This definition references both the workplace and the 'individual', and in doing so encapsulates the notion of an individual's identification with the workplace. Individual identity relates to gender, even though the literature on employee's identity within academia sometimes disregards the importance of gender altogether (e.g. Gioia and Thomas, 1996).

Women's workplace identity is constructed and reconstructed as outside the image of the successful academician who is traditionally depicted as male (Cheryan et al., 2009; Gorman, 2005). Ryan (2012, p.552) references gender through a construction of social identity in academia, as dominated by males in a "gendered, hierarchical institutional space". This is perhaps not surprising given the low numbers of academic women, and their relatively recent access to the profession,

although women .... are making their way into previously homogeneous roles and occupations, organizational and occupational entry, socialization, and promotion processes are often based upon the images of previous successful workers (Ramarajan et al., 2013, in press, p.7).

Organisational culture builds the value of work, and in academia, "the typical career path in academia is structured according to a male perception of success which involves being research active" (Haynes and Fearfull, 2008, p. 189). Although research is claimed as the "real business" of academia, the identity of a faculty member is composed of other roles as well, i.e. in teaching, service and administration (Haynes and Fearfull, 2008, p. 189). Women tend to follow, overwork and out-perform criteria for each role that is assigned to them (Chan, 1996; Mamiseishvili, 2010; Newall and Bradshaw, 1998; Omundson and Mann, 1994), yet "teaching, organizing, administrative duties and looking out for the welfare of 
colleagues are less valued" (Bleijenbergh et al., 2012, p. 24). Women's workplace identity is lessened because their contribution is not rated as 'real' business (Haynes and Fearfull, 2008), and women's identification with the academic workplace will be negatively affected when their work is undervalued.

The literature reviewed so far highlights the extent of women's presence in academia through a number of metaphors; they vanish; they are lost; there is a leaky pipeline; they suffer pin pricks (Allan, 2011; Blickenstaff, 2005; Hopfl and Matilal, 2007; Morley, 2014). Women are challenged in academia to have their identities valued and to feel comfortable within its "patriarchal system" (Todd, 2008, p. 767). The tension that women experience between their workplace identity as academics and their non-work identity as women (Ramarajan et al., in press), sensitises them to the largely masculine nature of their surroundings and its symbols. We now turn to how women's identification with the workplace and women's identity in academia is socially constructed through the symbolic meaning of artifacts.

\section{Symbolic meaning from workplace artifacts}

The qualities that represent a university have been studied in terms of behavioral factors; diversity, historical, and the psychological context, but have not yet expanded to encompass the physical campus (Allan, 2011). Warren (2002) considers emotions and other "nonrational elements of organizational life", including aesthetics and symbolism, have largely been hidden in organisations and written out of the study of management (Warren, 2008, p. 559). Such a conspiracy of silence is significant for women's commitment to the organisation, due to the value they place on internal environmental factors (Dodd-McCue and Wright, 1996; Verhaegen, 2005).

Present in the workplace are artifacts, i.e. "inanimate objects introduced by organisational members into their organisations" (Vilnal-Yavetz and Rafaeli, 2006, p.10). Hancock and Tyler (2007, p.515) consider that artifacts present in the organisation communicate meaning, 
and "are able to play a unique role in the constitution of values, beliefs and actions". An employee gains value in the workplace and identifies with that workplace through the "meanings or associations an artifact elicits" (Vilnal-Yavetz and Rafaeli, 2006, p.14). Warren (2002) argues:

when we look at something we do not just experience it with our eyes, rather its apprehension conjures up a whole host of thoughts and feelings based on our own experiences of what that image means to us within our own personal, social and cultural worlds (p. 234).

The aesthetics inherent in the design of artifacts trigger a subjective judgement, imaginary or real, that is significant to the beholder (Warren, 2008; Witz et al., 2003). Aesthetics give employees knowledge about the physical surroundings in which they work, due to the feelings and emotions invoked by the artifacts present within the environment (Dale and Gibson, 2002).

Warren (2002) recognises that organisations are replete with cues "that elicit feelings, emotional responses and value judgments about our work, workplaces, colleagues" (p. 225). For instance, a bank building is constructed through a choice of material (hard) and size (large) to trigger a judgment that the bank is secure and solid (Witz et al., 2003). The emotions associated with artifacts are worthy of exploration because positive or negative feelings are a consequence of job experiences and affect job satisfaction (Brief and Weiss, 2002; Kenny, 2008). However, although there has been extensive study of job satisfaction, there is little research on the link between physical settings and emotions/feelings/moods in the workplace (Brief and Weiss, 2002). Feelings are an element of the human existence, but an employee is expected to manage an emotion to avoid negative impact on clients or colleagues (Witz et al., 2003).

Artifacts offer visual cues to indicate and affirm the institutional and employee values, e.g. colour, materials used, and size (Elsbach, 2004). To illustrate, an office is an artifact in the internal workplace, and a large, corner office ('C-Suite') contains symbolic meaning about an 
employee's career progress and status (Burke, 2013; Elsbach and Bechky, 2007). Elsbach (2004) examines "how employees in corporate office environments interpreted a variety of relatively permanent office décor....as indicators of their colleagues' workplace identities" (p. 99), and argues that such important signals about identity will not, and should not, be ignored.

Workplaces are a proxy for the culture of an organisation whereby "symbols are external sources of information" (Strati, 1998, p. 1386). The symbolic meaning attributed by employees to their surroundings is emphasised by Strati (1998),

organizational actors are the subjects of the organizational culture. It is to them that it belongs; it is they who construct it and re-invent it; who enrich it with symbols; who attribute it with value and who draw meanings from it (p.1381).

The symbolic meanings of artifacts in workspaces require study, as currently we lack insight into an important organisational aspect that may create discrimination against women (Newell and Bradshaw, 1998). Dandridge et al. (1980) introduce the concept of 'organisational symbolism', where symbolic meaning is contained in communication, related to actions and found in material objects. We focus here on artifacts as material objects, and the extent to which women experience their symbolic meaning as expressive of a gender bias within the university.

The gendering of an organisation relies on the multiplicity of symbols that are often very visible upon entering the space for the first time (Strati, 1998). In time, the workplace symbols are familiar, and their presence may well become accepted, unnoticed or tolerated. The symbolic meaning attributed by individual employees will be different, but a particular social group (e.g. gender) develops an 'identity lens' towards a symbol. An indication of an identity lens is with respect to discrimination experiences, wherever the perceptions of the majority (males) are at variance with the perceptions of the minority (women) (Weisenfeld et al., 2007). For example, institutional surroundings can create "an impression of strength and 
virility or alternatively, one of care and intimacy", and where masculine symbols proliferate, "business [academia] reverberates with the great male saga of conquest" (Gheradi, 1995, p. $11)$.

Understanding how identity is played out in an organisation can be gained from consideration of the role that artifacts contribute to shaping the meaning of gender (Hancock and Tyler, 2007). Analysis of the photographs of women in an institutional artifact (brochure) reveals a representative of power and control in the body corporate (Carr and Hancock, 2002; Hancock and Tyler, 2007). The photograph lacks "any notable emotional reaction", as the female form is manipulated through a lack of make-up to fit the aesthetic of the more accepted other (i.e. male) gender in the organisation (Hancock and Tyler, 2007, p. 527). The result is woman becomes "an abject other", either because she is absent or, if present, has been fitted to a "non-place" within the organisation (Fotaki, 2013, p. 1255). Where one gender dominates the other, there will be more symbols of the majority in "the longing to clone" the other to be like themselves (Moody, 2004, p. 47). An example is in business dress, whereby "in business schools we [women] often dress in the corporate style to fit the dominant discourses of the masculine power structures" (Newall and Bradshaw, 1998, p. 125). As well, general wisdom purports that cloning oneself as 'the other' provides the path to success.

The organisational symbols that proliferate are contrasted with "the lack of woman's own symbols and systems of signification [which] positions her in the category of the stranger, the outsider and the other in academia" (Fotaki, 2012, p. 192). We are therefore interested in exploring the symbolic meaning of artifacts in the university, to the extent that these construct and reconstruct her identity as 'other', a stranger to, and located outside of the academic workplace (Fotaki, 2012). 


\section{Methodology}

A direction towards auto-ethnography, as a methodological approach, was chosen because it provides a connection between the consciousness of personal experience and the setting, in this case academia. Prior studies successfully applied the auto-ethnographic approach to study academia (Mendoza, 2008), gender in organisations (Haynes, 2011; Mischenko, 2005; Watson, 2010), and careers (Ryan, 2012). An auto-ethnographical approach facilitates the personal and immediate analysis of the researchers' direct experience (Styhre and Tienari, 2013). In the auto-ethnographic approach, the individual reflects and makes sense about involvement as a researcher, "given the space to figure out who we are as a person, fieldworker and writer" (Ryan, 2012, p. 544). Thus auto-ethnography enables us as participants, researchers and writers to "explore our somewhat conflicting identity positions as women" in academia (Haynes and Fearfull, 2008, p. 186) through reflection on "who am I (or 'who are we') and what do I (we) stand for?" (Sveningsson and Alvesson, 2003, p.1164). We move here to referencing ourselves in the narrative as 'we' or 'our' to support our autoethnographical approach.

\section{Data sample/participants}

The authors work together in a particular academic institution, and we have spent many years immersed in the 'field' of business academia as both agents (researchers/writers), and actors (faculty/administrators) (Van Maanen, 1988). Our nationalities are respectively British, Irish, and New Zealand/American, and we disclose such information to indicate our status as long term expatriates i.e. non-natives of this region. As an issue of research reliability, we are aware of subjectivity in our study because of our backgrounds. However, in that declaration there is appreciation for the multiculturalism of the setting. The university follows an American curriculum and policies, is located in the Middle East, and employs faculty and staff from over 80 countries. The size of the university in terms of student numbers $(6000+)$, 
and of the business school ( $>1500$ students), is comparable with others in the region. The university holds international and national accreditations. It is thus considered as an international institution of higher education.

We are, at the same time the observed and the observers, who "by researching autoethnographically, expose not only our research but ourselves to scrutiny" (Haynes, 2011, p.135). We are mindful of the risk to our identities in our own workplace by undertaking this exploration of women in academia (Newall and Bradshaw 1998) because, as O'Connor et al. (1999) state, there is a "devaluation of women's scholarship, expertise and achievements, including devaluation of scholarship on women's issues" (p.12). We research and publish about the topic, however, because as members of the minority gender in business academia, our percentage of 'voice' is somewhat silenced within the organisational workplace (Haynes, 2011; Ryan, 2012).

\section{Data collection}

Our auto-ethnographical journey began with data collection in May 2013 when the call for papers for this special edition was shared between the authors. Between then and the end of July, when we submitted, we met frequently both face to face and virtually to share thoughts on the direction for the study, to overview literature, and to discuss our methodological progress.

Physical meetings were usually twice a month, during coffee or lunch, and we maintained notes of those meetings. Our email exchanges were more frequent and very often daily, and the lead author maintained a record of these contributions (141 emails/145 pages). Through face-to-face meetings and via emails we dialogued about our observations of the university environment. Individually, over a period of ten days, we formally wrote a daily reflective journal recording our experience of the workplace. On average, we spent one hour or more per day on this personal reflection as we went about our normal business. Occasionally the 
journal was written as something occurred, but due to the limitations in doing so, there was also writing that occurred post event. The culmination of this written journal was twelve pages of personally significant observations about the workplace. Two of us wrote in note format with bullet points, and another in a more flowing narrative style. We had not dictated a particular style for recording in order to avoid constraints on reflective flow. A conscious effort was made to avoid prejudicing or prioritising any particular aspect of individual identity in this qualitative study (Denzin and Lincoln, 1998; Holliday, 2001; Stake, 2010). We finally shared our reflective journals through e-email, and each read about the others' experiences before meeting to discuss the outcome of our work.

\section{Analysis}

Each auto-ethnographic journal was submitted to Nvivo 9, software to support qualitative research analysis (Hammersley, 2008). The results were coded based on keyword searches, as well as a thorough reading and re-reading of the context in each journal. Firstly, words and phrases that referred to artifacts, their descriptions and aesthetics were coded. These results enabled the three authors to hold more informed discussion about the artifacts of interest and to attribute symbolic meaning. Then our analysis became a deeper conversation as we sought convergence about adjectives, and phrases through all the journals. In the process of analytical discussion we included a reliability check because as auto-ethnographers we are aware of the subjectivity of self - analysis, and that this is an element of the research approach. It was advantageous to be co-authors in the process so that our analysis was not a reflection of one interpretation, but a collegial decision amongst female faculty members who "value collegial relationships within an academic community" (Santo et al., 2009, p. 120). Final decisions about emergent themes of symbolic meaning evolved through a process of agreement and disagreement about the collected data (Carruthers et al., 2008). 
A framework used in a previous study on organisational artifacts guided our analysis (Elsbach, 2006). That study focused on a corporate office environment, and was of interest because of the business setting. Furthermore, the framework relied on the interpretation of the symbolic meaning by observers and displayers. As our study is an auto-ethnographical approach, we are observers of the scene, and are 'displayers' when we reference dress and office paraphernalia. In Elsbach (2006), the framework also includes some of the artifacts that were referenced in the literature review, and in our study; photos; dress; posters. The Elsbach (2006) study was an initial reference point, although our research extends outside the office to incorporate artifacts beyond that confine.

The resulting framework constructed in our study is displayed in Table 1.

Table 1 Analytical framework - goes here.

Our analysis is an interpretation of how women experience the university environment through the emotions triggered by artifacts classified as architectural, institutional and personal. Architectural artifacts are the buildings, car-parks, corridors, and courtyards. The décor, furnishings, notice boards, photographs, pictures, technology, security guards are classified as institutional artifacts. Dress, shoes, bags are designated as personal artifacts. The descriptions include the material from which artifacts are constructed e.g. marble for courtyards and the fabric covering of chairs. Also of interest were colour e.g. a green notebook, length of corridors, the size and shape of buildings, and rooms. The ethnographer's subjective judgment of the aesthetics were identified through the emotions described, e.g. confusion, fear, loneliness, discomfort. Quotations emanate from each of the reflective journals, serving to illustrate the analysis, and to provide references for the findings and discussion.

\section{Findings}


The findings were classified into three emergent themes about the symbolic meaning of workplace artifacts for women in academia. These themes were: 'affect', i.e. women are uncomfortable with their surroundings; 'representation', i.e. women are rendered invisible in the physical environment; and 'surveillance', i.e. women feel monitored in the workplace. The findings are illustrated below to capture, from the collected qualitative data, the essence or impression of an observation (Stake, 2010; Ylijoki, 2005).

\section{Affect}

The aesthetics of some artifacts are deemed uncomfortable, for instance there is little artwork and more wrought iron. The harshness of the materials used to construct the seating and tables (e.g. wood, metal) cause a participant to yearn for some tapestry or cushions. The question of comfort also arose in relation to the size and appearance of personal office space, people always ask me why I didn't take the bigger office, .... if I had such an office, I would still want to make it comfortable and cozy. Physical discomfort is experienced as we walk across courtyards constructed of marble tiles: very slippy flooring especially with any kind of heel. There is a lack of comfortable seating, catering staff outside my door has no chair, she is sitting on a cooler box. Emotional discomfort emerges through the confusion created due to a lack of directional signage, not a lot of information available.

\section{Representation}

The aesthetics of the buildings are described in comparison to the human condition, where buildings are "huge", "wide", and we women feel dwarfed because of our smaller physical stature. The length of corridors, and the lack of people enforce a feeling of isolation, e.g. the long corridors - they are empty.... I am walking the long straight corridors alone. It is a hierarchical space that is male dominated as the walls are adorned with pictures of senior men. The photographs not only project to us a sense of being under scrutiny from these 
permanent images, but also emphasise a lack of women in the environment. Handbags are carried that have to be literally opened up during routine security searches, physically opening women's personal possessions to intense scrutiny. Our clothing, and that of the female students confounds the technology used in the business school, e.g. try putting a lapel mike on when you are not wearing clothes to accommodate. We wear brightly coloured clothing that marks us out against the sombre tones of the buildings and furnishings, and are in comparison to the monochrome business attire worn by others (usually men).

\section{Surveillance}

It is 'the others' who monitor the women. An illustration of this is found in the car-park: $I$ drive into parking - uniformed security guards all about during morning rush. At the beginning of the working day, we enter a workplace through a physical barrier that is supervised by male security guards. The guards peer in the car windows to match faces with identity cards. There is also the element that surveillance could have been avoided through entitlement to a private/allocated parking space, if only she had known. The courtyard benches are occupied, and again the author is subject to the scrutiny of men sitting there, feel them watching me. All around are artifacts that indicate that when we are seen, there is surveillance of that presence.

The discussion that follows brings together the literature review and the findings in this study. It considers the emergent themes of symbolic meaning from artifacts that impact on the inclusion and opportunity for women in academia. Following that discussion, the limitations of the study are contemplated the implications for further research are outlined.

\section{Discussion}

The symbolic meaning obtained from these artifacts emerged as we, the authors, attempted to make sense of our surroundings (Maitlis, 2005). Sense-making is a key feature to the 
creation of a workplace identity wherein, via a reflective process, sense is made of who we are through either an internal dialogue or through recounting our stories of experience to others (Reissner, 2010). This was true for the authors' auto-ethnographies, where we initially reflected in our journals, and then through dialogue about our experiences we discovered layers of meaning projected through the artifacts.

For women in academia, the symbolic meaning in the workplace environment is one of discomfort, where they are invisible or un-represented, while at the same time they are placed under surveillance. We found the condition of the environment to be important because, as our journal entries (data) demonstrate, our shared experiences ranged from uncomfortable, $I$ always thought the courtyards .... were so strange, with nothing in them - ... - not about comfort, to dangerous, as we struggled to negotiate broken tiles and slippery flooring. The authors note that the workplace contains mainly artifacts made of 'hard' material (iron, stone, marble), and lack a softness of materials such as cushions, tapestries. There is confusion in a lack of signage and untidy noticeboards. The symbol of a bigger office is one of increased status, but even in knowing that, there is the preference for comfort and privacy in choice of individual office. In the process of discovering one's workplace identity, pinpricks from the artifacts in the surroundings cause women discomfort, if not also rendering them somewhat "fearful" (Newall and Bradshaw, 1998, p. 126). In this study there was fear of literally falling, and fear of a loss of status when choosing comfort. The metaphor of "death by a thousand pin pricks" developed an interesting symmetry with the emerging symbolism of our surroundings (Todd et al., 2008, p 767).

Through the journals, all three auto-ethnographers noted being passively and actively watched or monitored. There is a requirement to negotiate through a physical workplace where women are actively monitored by guards, and passively watched by men sitting on a bench. Women are missing in the institutional images, and are under permanent passive 
surveillance from males peering down from the photographs. Entitlement to a private parking place was unknown, until another woman pointed out the right, the interpretation was that such knowledge leads to more comfort (private and nearer parking space), and to less surveillance (guards know one). However, the significance was that the symbolic meaning of that artifact continued for women because of an absence of that knowledge. It is left 'unknown' how we can access such information. There were journal entries that revealed our clothing style and colour contrasted sharply against sombre architecture. As well, the dress of the women marked them in a contrast to monochrome business suits worn by the majority. A paradox arose from an interpretation of the artifacts where women are marked by their appearance (Tannen, 2001), are monitored by others and yet are also rendered 'invisible' through a lack of representation.

Thus, our study has shown that workplace artifacts contain symbolic meaning for women in academia, and of particular significance are those we classified as architectural, institutional and personal. Women's identification with the workplace environment is challenged because of the negative emotions aroused from these artifacts. The longer they remain in an institution of higher education, the more 'pin pricks' women in academia experience causing discomfort with their surroundings; a heightened feeling of invisibility; expectations of surveillance (Todd et al., 2008). The leaking pipeline of women is then exacerbated as they leave academia because of discomfort with the setting, lack of representation and evidence of surveillance (Blickenstaff, 2005). An overarching emergent theme is the symbolic meaning of workplace artifacts that identify women in academia as 'outsiders' to the university environment (Fotaki, 2012).

\section{Limitations and future research direction}

This study is limited in that it reflects an auto-ethnography by a small number of women in one academic institution in one country. Thus we cannot claim our framework is 
generalisable to other settings, it is an initial study and deeper analysis of the symbolic meaning of workplace artifacts for women is warranted. An implication is to involve female academicians from many nationalities to extend the study to other academic institutions in further countries. Future research can apply the auto-ethnographic approach and our framework to determine the impact of symbolic meaning on the inclusion and opportunity for women in academia.

\section{Conclusion}

Workplace identity for women in academia is constructed and reconstructed as they attribute symbolic meaning to the architectural, institutional and personal artifacts that surround them. We classified our findings into themes of affect, representation and surveillance that imbue artifacts as an institutional issue because of the symbolic meaning for women's inclusion and opportunity in academia.

The practical implication is that women's identification with the workplace is lessened because of the negative emotions they experience from artifacts. Lester (2011) concludes that "[c]reating an environment that is accepting of all will only be successful if individuals can represent their identities without fear and without the need to manage impressions" ( $\mathrm{p}$. 177). This is important, particularly for business schools, as there are few women in comparison to men, and the higher the professional status, the lower the representation of women in the profession.

A theoretical contribution is that the architectural, institutional and personal artifacts in a university campus have not previously been taken into account for their impact on women's inclusion and opportunity in academia. We have investigated a link between feelings about identity and the physical setting that is a contribution to previous research findings. Furthermore, this study contributes a unique non-western setting to add to other research 
findings about women in academia. The ultimate value of this study is that it adds to the body of knowledge on the symbolic meaning of artifacts for women's workplace identity.

\section{References}

AACSB International-The Association to Advance Collegiate Schools of Business (AACSB) (2013), "Data and Research", available at http://aacsb.edu/dataandresearch/dataglance/ (accessed July, 2013).

Allan E. J. (2011), "Women's status in higher education: Equity matters" ASHE Higher Education Report, Vol. 37 No. 1, pp. 28, 65-92.

Alvesson, M. and Willmott, H. (2002), "Producing the appropriate individual: Identity regulation as organizational control", Organization, Vol. 15 No. 1, pp. 5-28.

Bleijenbergh, I. L., Van Engen, M.L. and Vinkenburg, C. J. (2013), "Othering women: Fluid images of the ideal academic", Equality, Diversity and Inclusion: An International Journal, Vol. 32 No. 1, pp. 22-35.

Blickenstaff, J. C. (2005), "Women and science careers: leaky pipeline or gender filter?" Gender and Education, Vol. 17 No. 4, pp. 369 - 386

Brief, A. P., \& Weiss, H. M. (2002), "Organizational behavior: Affect in the workplace”, Annual Review of Psychology, Vol.53 No. 1, pp. 279-307.

Burke, D. (May 23, 2013), "What business schools must do to put more women in the Csuite", Huffington Post, available at http://www.huffingtonpost.com/daria-burke/whatbusiness-schools-women_b_2234022.html (accessed July 20, 2013).

Carr, A., \& Hancock, P. (2002). Art and aesthetics at work: An overview. Tamara : Journal of Critical Postmodern Organization Science, 2(1), 1-7.

Carruthers, J., Ashill, N.J. and Rod, M. (2008), "Purchaser-provider interaction in the UK public healthcare sector: Strategies to improve stakeholder cooperation", Journal of Retailing and Consumer Services, Vol. 15 No. 1, pp. 22-31.

Chan, Y. E. (1996), "Going the extra Mile'” in Cyr, H. and Reich, H. (1996), Scaling the ivory tower: Stories from women in business school faculties, Greenwood Press, CT, USA.

Chanana, K. (2003), "Visibility, gender, and the careers of women faculty in an Indian University", McGill Journal of Education, Vol. 38 No. 3, pp. 381-389.

Cheryan, S., Plaut, V. C., Davies, P., and Steele, C. M. (2009), “Ambient belonging: How stereotypical cues impact gender participation in computer science, Journal of Personality and Social Psychology, Vol. 97 No.6, pp. 1045-1060.

Dale, K., \& Gibson, B. (2002). An-aesthetics and architecture. Tamara : Journal of Critical Postmodern Organization Science, 2(1), 77-90. 
Dandridge, T. C., Mitroff, I. and Joyce, W. F. (1980), "Organizational symbolism: A topic to expand organizational analysis", Academy of Management. The Academy of Management Review, Vol. 5 No. 1, pp. 77.

Denzin, N. K., and Lincoln, Y. S. (1998), The Landscape of Qualitative Research, Theories and Issues, CA: Sage.

Dodd-McCue, D. and Wright, G. B. (1996), "Men, women, and attitudinal commitment: The effects of workplace experiences and socialization”, Human Relations, Vol. 49 No. 8, pp. $1065-1065$

Dutton, J. E., Dukerich, J. M. and Harquail, C. V. (1994), "Organizational images and member identification”, Administrative Science Quarterly, Vol. 39 No. 2, pp. 239-263.

Elsbach, K. D. (2004), “Interpreting workplace identities: The role of office décor", Journal of Organizational Behavior, Vol. 25 No. 1, pp. 99-128.

Elsbach, K.D. (2006), "Perceptual biases and misinterpretation of artifacts", in Rafaeli, A. and Pratt, M.G., Artifacts and Organizations: Beyond Mere Symbolism, Lawrence Erlbaum, Mahwah, N.J.

Elsbach, K.D. and Bechky, B.A. (2007), "It's More Than A Desk: Working Smarter Through. Leveraged Office Design, California Management Review, Vol. 42 No.2, pp. 80-101.

Ely, R. J. (1995). "The power of demography: Women's social constructions of gender identity at work", Academy of Management Journal, Vol. 38 No. 3, pp. 589-534.

Exum, W. H., Menges, R. J., Watkins, B. and Berglund, P. (1984), "Making it at the top women and minority faculty in the academic labor market", The American Behavioral Scientist (Pre-1986), Vol. 27 No. 3, pp. 301.

Fotaki, M. (2012), “The consequences of woman's absence from the body of knowledge: The experience of female lecturers in business and management schools in England", In Festić, F. (Ed.), Gender and Trauma Interdisciplinary Dialogues, Newcastle-upon-Tyne, UK: Cambridge Scholars, pp. 191-215.

Fotaki, M. (2013), "No woman is like a man (in academia): The masculine symbolic order and the unwanted female body", Organization Studies, Vol. 34 No. 9, pp.12511275 .

FT.com (2012), "Global MBA ranking, 2013”, "European Business School rankings 2012", available at http://rankings.ft.com/businessschoolrankings/rankings (accessed July, 2013).

Fujita, F. (2006), “The status of women faculty: A view from Japan”, Journal of Women's History, Vol. 18 No.1, pp. 177-180.

Gioia, D. A. and Thomas, J. B. (1996), "Identity, image, and issue interpretation:

Sensemaking during strategic change in academia", Administrative Science Quarterly, Vol. 41 No.3, pp. 370. 
Gheradi, S. Gender, symbolism and organizational cultures, London: Sage, 1995.

Gorman, E. H. ( 2005), "Gender stereotypes, same-gender preferences, and organizational variation in the hiring of women: Evidence from law firms", American Sociological Review, Vol. 70 No. 4, pp. 702-728.

Grove, J. (2013), "At the heart of the Higher Education debate THE global gender index", available at http://www.timeshighereducation.co.uk/features/the-global-genderindex/2003517 (accessed 12 July 2013).

Hammersley, M. (2008), Questioning Qualitative Enquiry: Critical Essays, London, Sage.

Hancock, P., \& Tyler, M. (2007). Un/doing gender and the aesthetics of organizational performance. Gender, Work \& Organization, 14(6), 512-533.

Haynes, K. (2011), "Tensions in (re)presenting the self in reflexive autoethnographical research", Qualitative Research in Organizations and Management, Vol. 6 No. 2, pp. 134149.

Haynes, K. and Fearfull, A. (2008), "Exploring ourselves: Exploiting and resisting gendered identities of women academics in accounting and management", Pacific Accounting Review, Vol. 20 No. 2, pp. 185-204.

Hopfl, H., \& Matilal, S. (2007). "The lady vanishes": Some thoughts on women and leadership. Journal of Organizational Change Management, Vol. 20 No. 2, pp. 198-208.

Holliday A. (2001), Doing and Writing Qualitative Research, London, UK: Sage.

Jackson, P.B., P.A. Thoits, and H.F. Taylor (1995), "Composition of the workplace and psychological well-being: The effects of tokenism on America's black elite, Social Forces, Vol. 74, No. 2, pp. 543-557.

Kenny, K. (2008). Aesthetics and emotion in an organisational ethnography. International Journal of Work Organisation and Emotion, 2(4), 374-388.

Kirk, D. and Napier, D. (2009), "Issues of gender, equality, education, and national development in the United Arab Emirates", International Perspectives on Education and Society, Vol. No. 10, pp. 301-331.

Lester, J. (2011), "Acting on the collegiate stage: Managing impressions in the workplace", Feminist Formations, Vol. 23 No. 1, pp.155-181.

Maitlis, S. (2005), "The social processes of organizational sense making”, Academy of Management Journal, Vol. 48 No.1, pp. 21-49.

Mamiseishvili, K. (2010), "Foreign-born women faculty work roles and productivity at research universities in the United States", Higher Education, Vol. 60 No.2, pp. 139-156.

Mendoza, P. (2008), "Socialization to the academic culture: A framework of inquiry", Revista De Estudios Sociales, No.31, pp. 104-117. 
Mischenko, J. (2005), "Exhausting management work: Conflicting identities", Journal of Health Organization and Management, Vol. 19 No. 3, pp. 204-218.

Moody, J. (2004), “Supporting women and minority faculty”, Academe, Vol. 90 No. 1, pp. 47-52.

Morley, L. (2014). Lost leaders: Women in the global academy. Higher Education Research \& Development, Vol. 33 No. 1, pp. 114-128.

Newell, S. and Bradshaw, P. (1998), "Dreams of untenured female faculty: Exploring the deep structures of power”, Canadian Woman Studies, Vol. 18 No. 1, pp. 123-127.

O'Connor, J., Zeytinoglu, I. U., Denton, M. and Ahmed, M. (1999), “Gender patterns in faculty participation: A decade of experience at a mid-sized university", The Canadian Journal of Higher Education, Vol. 29 No. 2, pp. 1-32.

Omundson, J. S. and Mann, G. J. (1994), "Publication productivity and promotion of accounting faculty women: A comparative study", Journal of Education for Business, Vol. 70 No. 1, pp. 17-17.

Ramarjan,L., McGinn, K. and Kolb, D. (2012), "An outside-inside evolution in gender and professional work", Working Paper, No. 13-051, Harvard Business School.

Ramarajan, L. and Reid, E. (2013), "Shattering the myth of separate worlds: Negotiating nonwork identities at work", in press at Academy of Management Review.

Reissner, S. C. (2010). "Change, meaning and identity at the workplace", Journal of Organizational Change Management, Vol. 23 No. 3, pp. 287-299.

Riad, R. (2011). Invoking Cleopatra to examine the shifting ground of leadership. The Leadership Quarterly, 22.831-850.

Ryan, I. (2012) "A career journey: An auto-ethnographic insight", Gender in Management: An International Journal, Vol. 27 No. 8, pp. $541-558$.

Santo, S. A., Engstrom, M. E., Reetz, L., Schweinle, W. E., and Reed, K. (2009), "Faculty productivity barriers and supports at a school of education", Innovative Higher Education, Vol. 34 No. 2, pp. 117-129.

Stake, R.E. (2010), Qualitative research: studying how things work, Guilford Press, New York.

Stout, P. A., Staiger, J., and Jennings, N. A. (2007), “Affective stories: Understanding the lack of progress of women faculty”, NWSA Journal, Vol. 19 No. 3, pp. 124-144.

Strati, A. (1998), "Organizational symbolism as a social construction: A perspective from the sociology of knowledge", Human Relations, Vol. 51 No.11, pp. 1379-1402. 
Styhre, A. and Tienari, J. (2013), "Research agora: Self-reflexivity scrutinized: (profeminist men learning that gender matters", Equality, Diversity and Inclusion: An International Journal, Vol 32 No. 2, pp. 195-210.

Sveninggson, S. and Alvesson, M. (2003), "Managing managerial identities: Organisational fragmentation, discourse and identity struggle", Human Relations, Vol. 56 No.10, pp. 11631193.

Tannen, D. (2001), Talking from 9 to 5 - Women and Men at Work, New York: Quill.

Tapia, A and Kvasny, L(2004),"Recruitment is never enough: Retention of women and minorities in the IT workplace", SIGMIS'04, April 22-24, Tucson, Arizona, USA, pp. 84 91.

Todd, Z., Madill, A., Shaw, N., and Bown, N. (2008), "Faculty members' perceptions of how academic work is evaluated: Similarities and differences by gender", Sex Roles, Vol. 59 No. 11, pp. 765-775.

Van Maanen, J. (1988), Tales of the Field, University of Chicago Press, Chicago, IL.

Verhaegen, P. (2005), "Academic talent: Quo vadis?", Journal of Management Development, Vol. 24 No. 9, pp. 807 - 818.

Vilnal-Yavetz, I. and Rafaeli, A. (2006), "Managing artifacts to avoid artifact myopia", in A. Rafaeli and M.G. Pratt, Artifacts and organizations: beyond mere symbolism, Lawrence Erlbaum, Mahwah, N.J, pp. 9-23.

Warren, S. (2002), "Show me how it feels to work here: Using photography to research organizational aesthetics", Ephemera: Theory and Politics in Organizations, Vol. 2 No. 3, pp $224-245$.

Warren, S. (2008), "Empirical challenges in organizational aesthetics research: towards a sensual methodology", Organization Studies, Vol. 19 No. 4, pp. 559 - 580

Watson, T. (2011), "Ethnography, reality and truth: The vital need for studies of 'how things work' in organizations and management", Journal of Management Studies, Vol. 48 No.1, pp. 202-217.

Weisenfeld, L. W., and Robinson-Backmon, I. (2007), “Accounting faculty perceptions regarding diversity issues and academic environment", Issues in Accounting Education, Vol. 22 No.3, pp. 429-445.

Witz, A., Warhurst, C., \& Nickson, D. (2003), "The labour of aesthetics and the aesthetics of Organization” Organization, Vol. 10 No. 1, pp. 33-54.

Ylijoki, O. (2005), "Academic nostalgia: a narrative approach to academic work," Human Relations, Vol. 58 No. 5, pp. 55 
Table 1 Analytical framework

\begin{tabular}{|c|c|c|c|c|}
\hline \multicolumn{2}{|c|}{ PHYSICAL ARTIFACT } & \multicolumn{3}{|c|}{ OBSERVER"S INTERPRETATIONS } \\
\hline Artifact & Description & $\begin{array}{l}\text { Aesthetics } \\
\text { (emotions) }\end{array}$ & Illustrative quotations & $\begin{array}{c}\text { Emergent themes } \\
\text { of symbolic meaning }\end{array}$ \\
\hline \multicolumn{5}{|c|}{ Architectural Artifacts } \\
\hline Buildings & Size & $\begin{array}{l}\text { Vast } \\
\text { Unadorned } \\
\text { Hard fabrics } \\
\text { Unappealing } \\
\text { Uncomfortable }\end{array}$ & $\begin{array}{l}\text { "Huge, wide-open spaces. .... little artwork, unadorned -main } \\
\text { decoration is architecture." } \\
\text { "Building more marble with addition of wrought iron - a new twist } \\
\text { in the décor; yearn for some tapestry or cushions". }\end{array}$ & \multirow{4}{*}{$\begin{array}{l}\text { 'Affect' } \\
\text { Women are uncomfortable } \\
\text { with their surroundings } \\
\text { Surveillance' } \\
\text { Women are monitored by } \\
\text { the other }\end{array}$} \\
\hline Car-parks & $\begin{array}{c}\text { Barriers - } \\
\text { human and } \\
\text { automatic }\end{array}$ & $\begin{array}{c}\text { Fear } \\
\text { Uninformed } \\
\text { Rushed }\end{array}$ & $\begin{array}{l}\text { "Drive into parking - uniformed security guards all about during } \\
\text { morning rush." } \\
\text { "I had to pester people for it [parking space], and not sure what I } \\
\text { would have ended up with otherwise. I actually had a right to a } \\
\text { parking space when I took my current role, but no one ever informed } \\
\text { me and I never thought to ask". }\end{array}$ & \\
\hline Corridor & Length & $\begin{array}{c}\text { Lonely } \\
\text { Isolated } \\
\text { Uncomfortable }\end{array}$ & $\begin{array}{l}\text { "Long corridors with minimal decoration". } \\
\text { "The long corridors - they are empty.... I am walking the long } \\
\text { straight corridors alone." } \\
\text { "Notice catering staff outside my door has no chair - she is sitting on } \\
\text { a cooler box - give her a chair from my office." }\end{array}$ & \\
\hline Courtyard & $\begin{array}{l}\text { Marble } \\
\text { Bench }\end{array}$ & $\begin{array}{l}\text { Slip } \\
\text { Intimidation } \\
\text { Empty } \\
\text { Being watched } \\
\text { They are relaxed }\end{array}$ & $\begin{array}{l}\text { "I always thought the courtyards .... were so strange, with nothing in } \\
\text { them }-\ldots . .- \text { not about comfort, more about intimidation." } \\
\text { "Very slippy flooring especially with any kind of heel". } \\
\text { " } 3 \text { men ... sitting on bench...(not regular students) - feel them } \\
\text { watching me - they have their feet on the bench." }\end{array}$ & \\
\hline
\end{tabular}

Linzi J. Kemp, Linda Angell, Linda McLoughlin, (2015) "The symbolic meaning of artifacts for the workplace identity of women in academia", Gender in Management: An International
Journal, Vol. 30 Issue: 5, pp.379-396, https://doi.org/10.1108/GM-07-2013-0080 


\begin{tabular}{|c|c|c|c|c|}
\hline \multicolumn{4}{|c|}{ Personal Artifacts } & \multirow{5}{*}{$\begin{array}{l}\text { 'Representation' } \\
\text { Women are } \\
\text { unrepresented/invisible }\end{array}$} \\
\hline Dress & $\begin{array}{l}\text { Colour } \\
\text { Handbag } \\
\text { Clothing }\end{array}$ & $\begin{array}{l}\text { Dissimilar to the norm } \\
\text { Invasion of body } \\
\text { Non accommodating to } \\
\text { technology }\end{array}$ & $\begin{array}{l}\text { "Men look the same in suits." } \\
\text { "Notice I am only one wearing bright colors - also my notebook is } \\
\text { green and my pen has pink ink." } \\
\text { "Women had their bags searched." } \\
\text { "We are in a huge teaching room and need to use a lapel mike, at } \\
\text { this point I realise that we've never done this before. So try putting a } \\
\text { lapel mike on when you are not wearing clothes to accommodate. } \\
\text { You can pin the microphone, but where do you put the transmitter?" }\end{array}$ & \\
\hline \multicolumn{4}{|c|}{ Institutional Artifacts } & \\
\hline Decor & $\begin{array}{c}\text { Posters } \\
\text { Photographs }\end{array}$ & $\begin{array}{l}\text { Confusing } \\
\text { Untidy } \\
\text { Looking at us }\end{array}$ & $\begin{array}{l}\text { "Not a lot of information available - even sandwich boards often } \\
\text { mystifying". } \\
\text { "There are a lack of directions, I find myself still looking for } \\
\text { classrooms." } \\
\text { "Beige noticeboards - dirty looking." } \\
\text { "Photos in Main Auditorium - male rulers." } \\
\text { "Posters of student elections - many female students." }\end{array}$ & \\
\hline Furniture & Table & $\begin{array}{c}\text { Absence of females } \\
\text { Hierarchical } \\
\text { Superiority of the other }\end{array}$ & $\begin{array}{l}\text { "At lunch, top table again largely male - male servers stand behind } \\
\text { them." } \\
\text { "People always ask me why I didn't take the bigger office, and act } \\
\text { like I should have .... But I really don't want that space! ....Sure, I } \\
\text { wouldn't mind having a big office with a nice window, and a view, } \\
\text { and space for a table, etc. But....if I had such an office, I would still } \\
\text { want to make it comfortable and cozy - with comfy sofas, etc. I feel } \\
\text { I spend an awful lot of time in my office, so it should be comfortable } \\
\text { and reflect my personality." }\end{array}$ & \\
\hline
\end{tabular}

